\title{
PENINGKATAN PENGUASAAN KONSEP IPA MELALUI \\ PENDEKATAN KONTEKSTUAL PADA SISWA KELAS VA SDN 064960 KECAMATAN MEDAN POLONIA
}

\author{
Megawati \\ Surel:megawati07@gmail.com
}

\begin{abstract}
ABSTRAK
Penelitian ini bertujuan untuk peningkatan hasil belajar IPA melalui Pendekatan kontekstual,dengan penguasaan konsep pada siswa kelas V SD N 064960 Medan Polonia. Penelitian ini adalah penelitian tindakan kelas (Classroom Action Research). Penelitian ini dimaksudkan untuk memperbaiki proses pembelajaran sehingga dapat meningkatkan penguasaan konsep IPA siswa. Subjek penelitian adalah siswa kelas VA SD N 064960 Medan Polonia.berjumlah 36 siswa. Adapun indikator keberhasilan tindakan ditandai dengan $\geq 75 \%$ dari jumlah siswa yang mengikuti proses pembelajaran telah memperoleh nilai $\geq 70$. Hasil penelitian menunjukkan adanya peningkatan hasil belajar IPA siswa kelas VA SDN 064960 Medan Polonia. melalui Pendekatan kontekstual baik pada siklus I maupun siklus II. Pada siklus I siswa yang memperoleh nilai $\geq 70$ mengalami peningkatan sebesar $25 \%$ dengan kondisi awal $44 \%$ meningkat menjadi $69 \%$ dan pada siklus II mengalami peningkatan sebesar $28 \%$ menjadi $97 \%$. Nilai rata-rata hasil belajar pada siklus I mengalami peningkatan sebesar 8,75\% dengan kondisi awal 66,53 Nilai rata-rata kelas meningkat menjadi 78.8 , sedangkan persentase ketuntasannya meningkat menjadi $85 \%$.
\end{abstract}

Kata Kunci: Pendekatan Kontekstual, Penguasaan Konsep, IPA

\section{PENDAHULUAN}

Pendidikan di sekolah dasar

(SD) merupakan bagian dari pendidikan dasar yang menjadi pondasi bagi pendidikan yang lebih tinggi. Hal ini sesuai dengan UndangUndang Sistem Pendidikan Nasional No. 20 Tahun 2003 pasal 17 nomor 1 yang menyatakan bahwa "Pendidikan dasar merupakan jenjang pendidikan yang melandasi jenjang pendidikan menengah". Adapun dari sisi guru pembelajaran IPA dilakukan secara klasikal dengan metode ceramah, tanya jawab dan diskusi sedangkan pendekatan yang digunakan yaitu pendekatan konsep. Guru melakukan pembelajaran di kelas secara monoton sehingga siswa kurang dapat terlibat aktif dalam proses pembelajaran. Siswa menjadi pasif dan hanya menerima penjelasan yang diberikan guru. Pembelajaran menjadi sangat membosankan, siswa yang jenuh lebih memilih bermain, bercanda, dan mengobrol dengan temannya daripada mendengarkan penjelasan dari guru. mampu memecahkan masalah. Lembar latihan soal yang diberikan setelah

SD Negeri 064960 Kecamatan Medan Polonia 
penyampaian materi hanya 8 siswa yang dapat menyelesaikan soal dengan baik dari keseluruhan siswa yang berjumlah 20 .

Hasil ini menunjukkan bahwa kurang dari $50 \%$ siswa yang mampu menguasai konsep-konsep dalam IPA dan memecahkan masalah dalam soal dengan baik. Selain itu, hasil lainnya yang dilakukan peneliti selama empat kali menunjukkan bahwa siswa kurang bersungguh-sungguh dalam menerima materi pelajaran. Terlihat pada saat guru menyampaikan materi pelajaran aktivitas siswa bermacam-macam. Beberapa siswa menyimak pelajaran dengan sungguh- sungguh, sebagian lagi sibuk mengobrol dengan teman sebangku, bermain sendiri, dan bercanda dengan temannya. Pada saat guru memberikan kesempatan untuk bertanya siswa hanya diam. Ketika siswa diberikan latihan soal, siswa masih binggung dan mencoba membuka buku mencari jawaban.

Hal ini mengindikasikan bahwa proses pembelajaran IPA di kelas belum sesuai dengan hakikat pembelajaran IPA berupa proses dan produk. Siswa belum pernah melakukan penelitian sederhana dengan cara memanfaatkan alam sekitar untuk mendapatkan ilmu pengetahuan. sehingga siswa mengenal dan menyukai pelajaran IPA sebagai pelajaran yang menyenangkan.

Berdasarkan latar belakang masalah, maka permasalah dalam penelitian ini adalah sebagai berikut.

1. Kurangnya tingkat penguasaan konsep IPA siswa.

2. Penggunaan alat peraga berupa KIT IPA kurang maksimal dalam pembelajaran.

3. Kurangnya inovasi dalam pembelajaran, sehingga mengakibatkan siswa kurang aktif dan sulit mengeluarkan ide-ide dalam pembelajaran.

Berdasarkan identifikasi masalah di atas, maka penelitian ini dibatasi pada penguasaan konsep IPA siswa kelas VA SD Negeri 064960 Medan melalui pendekatan kontekstual. Berdasarkan pembatasan masalah di atas, maka rumusan penelitian ini adalah sebagai berikut: "Bagaimana peningkatan penguasaan konsep IPA siswa setelah diterapkan pendekatan kontekstual (Contextual Teaching and Learning) pada siswa kelas VA SD Negeri 064960 Medan?"

Penelitian ini bertujuan untuk meningkatkan penguasaan konsep IPA siswa kelas VA SD Negeri 064960 Medan melalui pendekatan kontekstual (Contextual Teaching and Learning).

Penelitian ini bertujuan untuk meningkatkan penguasaan konsep IPA siswa kelas VA SD Negeri 064960 Medan melalui pendekatan kontekstual (Contextual Teaching and Learning). Penelitian ini diharapkan dapat memberikan 
sumbangan pada dunia pendidikan. Sumbangan tersebut berupa informasi dan pemikiran yang berguna untuk ilmu pendidikan yang terkait pada penguasaan konsep dan pendekatan pembelajaran.

1. Bagi siswa

Penelitian ini dapat membantu siswa mengatasi kesulitan dalam proses pembelajaran, khususnya pembelajaran IPA. Belajar dengan menggunakan pendekatan kontekstual (Contextual Teaching and Learning) dengan mengkaitkan kehidupan seharihari mendorong siswa untuk lebih menguasai konsep-konsep IPA.

2. Bagi guru

Penelitian ini membantu guru dalam memilih berbagai pendekatan pembelajaran yang cocok dilakukan di kelas. Guru akan lebih berinovasi dalam pembelajaran, menjadi bahan koreksi dan perbaikan agar guru dapat melaksanakan proses pembelajaran menjadi lebih baik.

\section{METODE PENELITIAN}

Penelitian ini berjenis penelitian tindakan kelas (classroom action research). Penelitian ini dimaksudkan untuk memperbaiki proses pembelajaran sehingga dapat meningkatkan penguasaan konsep IPA siswa. Menurut Suharsimi Arikunto (2006: 96) penelitian tindakan kelas (classroom action research), yaitu penelitian yang dilakukan. Penelitian ini dilakukan pada semester 1 tahun pelajaran 2014/2015, pada saat kegiatan belajar mengajar IPA berlangsung. Lokasi penelitian dalam penelitian tindakan kelas ini adalah kelas VA SD Negeri 064960 Medan.

Subjek penelitian ini adalah siswa kelas VA SD Negeri 064960 Medan. Siswa kelas VA SD Negeri 064960 Medan tahun ajaran 2014/2015 berjumlah 20 siswa, terdiri dari 8 siswa laki-laki, dan 12 siswa perempuan. Desain penelitian ini menggunakan model Kemmis \& Mc Taggart dengan tahapan perencanaan, tindakan (perlakuan) dan pengamatan, sertarefleksi. Untuk lebih tepatnya, berikut ini gambar bentuk desain PTK model. Penelitian tindakan kelas dapat dilakukan beberapa siklus. Setiap siklus dilakukan dengan alokasi waktu $2 \mathrm{x}$ 35 menit. Masing-masing siklus dalam penelitian tindakan kelas terdiri dari perencanaan, tindakan dan observasi, serta refleksi. Tahapantahapan akan dijabarkan sebagai berikut.

Tahap pertama, perencanaan yaitu dalam melakukan penelitian tindakan kelas yaitu mengindentifikasi masalah yang diteliti. Kegiatan dimulai dengan melakukan penelitian pada kelas yang diteliti dengan observasi langsung saat proses belajar mengajar berlangsung. Tahapan pelaksanaan tindakan pembelajaran dengan pendekatan kontekstual (CTL).

Selanjutnya observasi dilakukan untuk mengetahui 
memperoleh data meliputi kegiatan guru dan siswa ketika proses pembelajaran berlangsung di kelas. Observasi dilakukan berdasarkan lembar pengamatan pelaksanaan pembelajaran IPA menggunakan pendekatan konteksual.

Refleksi merupakan bagian yang sangat penting untuk memahami dan memberikan makna terhadap proses dan hasil pembelajaran yang terjadi. Tahap refleksi dilakukan untuk mengkaji dan merenungkan kembali kekurangan proses pembelajaran dan evaluasi tindakan. Refleksi dilakukan kolaboratif antara peneliti dan guru untuk perbaikan siklus selanjutnya.

Siklus II dilaksanakan apabila hasil refleksi siklus I belum mencapai keberhasilan yang telah ditetapkan. Dalam penelitian ini dilakukan tindakan sampai dengan siklus II.

Teknik pengumpulan data yang digunakan pada penelitian ini adalah observasi, dan tes.

\section{Observasi}

Observasi dilakukan peneliti secara langsung selama pelaksanaan tindakan sebagai upaya untuk mengetahui segala aktivitas guru dan siswa pada saat proses pembelajaran IPA di kelas. Observasi dilakukan dengan menggunakan lembar pengamatan prosedur pendekatan kontekstual untuk memperoleh data yang diperlukan.
2. Tes

Tes ini digunakan untuk mengukur hasil belajar siswa, khususnya tentang penguasaan konsep IPA siswa. Tes diberikan pada akhir siklus, digunakan untuk mengukur penguasaan konsep IPA siswa. Penelitian tindakan kelas juga dapat disebut penelitian deskriptif. Analisis data dilakukan secara deskriptif karena dilakukan dalam 1 (satu) kelas yaitu kelas VA SD Negeri 064960 Medan. Analisis kuantitatif digunakan untuk menganalisis hasil tes penguasaan konsep IPA yang berupa nilai rerata, sedangkan analisis data kualitatif digunakan untuk menganalisis hasil pengamatan siswa dan guru. Untuk menganalisis skor rerata penguasaan konsep IPA.

\section{HASIL DAN PEMBAHASAN}

Penelitian ini dilaksanakan dalam dua siklus. Siklus I dilaksanakan 2 kali pertemuan. Pertemuan pertama dilaksanakan tanggal 14 November 2015 dan pertemuan kedua tanggal 16 November 2015. Sebelum dilaksanakan tindakan penelitian, peneliti melaksanakan kegiatan pratindakan berupa observasi. Hasil observasi digunakan untuk mengetahui kondisi awal pembelajaran IPA siswa kelas VA SD Negeri 064960 Medan.

Observasi dilakukan untuk 
mengetahui sejauh mana penguasaan konsep IPA siswa kelas VA SD Negeri 064960 Medan pada pembelajaran IPA sebelum penerapan pendekatan kontektual. Berdasarkan hasil observasi yang dilakukan pada proses pembelajaran IPA di kelas VA SD Negeri 064960 Medan. Pembelajaran masih berpusat pada guru. Guru lebih dominan menggunakan metode ceramah, sehingga siswa menjadi kurang aktif. Dari hasil tersebut, diperoleh rerata untuk penguasaan konsep IPA siswa sebesar 60.6. Jumlah siswa yang mencapai kriteria keberhasilan sebanyak 8 siswa (40\%), sedangkan sebanyak 12 siswa $(60 \%)$ belum mencapai kriteria kebehasilan.

Berdasarkan hasil tersebut, maka peneliti dan guru bermaksud untuk memperbaiki dan meningkatkan penguasaan konsep IPA siswa kelas VA dengan penerapan pendekatan kontekstual. Pelaksanaan penelitian tindakan kelas dalam pembelajaran IPA materi"Tumbuhan Hijau dan Adaptasi Makhluk Hidup" siswa kelas VA SD Negeri 064960 Medan. Siklus pertama dilaksanakan dua kali pertemuan, dimana masing-masingpertemuan berlangsung selama 35 menit.

Siklus I pertemuan pertama dimulai dari tanggal 14 November 2015 dan pertemuan kedua pada tanggal 16 November 2015. Penelitian dilaksanakan pada semester I, yaitu sesuai dengan materi yang terdapat pada kurikulum pembelajaran kelas 5 SD.
Tahap perencanaan pada siklus I, peneliti dan guru menyamakan persepsi terhadap permasalahan siswa, yaitu masih rendahnya penguasaan konsep IPA siswa. Peneliti dan guru selanjutnya merancang pelaksaaan pemecahan masalah dalam kegiatan pembelajara IPA. Tahap kedua dari penelitian ini adalah pelaksanaan tindakan. Guru melaksanakan tindakan sesuai dengan rencana pembelajaran yang telah disusun oleh peneliti yang sebelumnya telah dikonsultasikan dengan guru kelas. Berikut deskripsi pelaksanaan pembelajaran IPA dengan pendekatan kontekstual dalam siklus I: Pertemuan pertama siklus I (Kamis, 14 November 2015) guru menyajikan materi "Tumbuhan Hijau" yang didalamnya memuat cara tumbuhan hijau membuat makanannya sendiri dengan bantuan cahaya matahari dan cahaya lain, serta tempat tumbuhan menyimpan cadangan makanannya.

Berdasarkan hasil penilaian produk tes penguasaan konsep IPA setelah tindakan siklus I, penguasaan konsep IPA meningkat dibanding dengan hasil UTS semester I pada saat pratindakan. Peningkatan ini ditunjukkan dengan meningkatnya skor rerata dari 60.6 pada hasil UTS Semester I saat pratindakan menjadi 69 pada penilaian setelah tindakan siklus I. Hal ini berarti terjadi peningkatan skor rerata 8.4. Sementara itu, siswa yang telah 
mencapai kriteria keberhasilan juga meningkat dari pratindakan sesuai hasil UTS semester I sebesar $40 \%$ menjadi $65 \%$ pada siklus I.Pada siklus II, penilaian produk tes penguasaan konsep IPA siswa meningkat dibanding penilaian produk pada siklus. Peningkatan ini ditunjukkan dengan peningkatan skor rerata dari 69 pada penilaian produk setelah tindakan siklus I menjadi 78.8 pada penilaian produk setelah tindakan siklus II. Hal ini berarti terjadi peningkatan skor rerata sebesar 9.8 dari penilaian siklus I. Siswa yang telah mencapai kriteria keberhasilan juga meningkat menjadi $85 \%$. Hal ini dirasa sudah cukup memuaskan karena kriteria keberhasilan yang telah ditentukan sudah tercapai yaitu sebanyak $75 \%$ siswa mencapai taraf keberhasilan. Peningkatan penguasaan konsep IPA siswa secara produk dalam pembelajaran IPA pada pratindakan sesuai hasil UTS Semester I, setelah tindakan siklus I, dan setelah tindakan siklus II. Peningkatan skor rerata dari pratindakan, siklus I, dan siklus II. Pada pratindakan diperoleh skor rerata 60.6 meningkat sebesar 8.4 menjadi 69 pada siklus I dan meningkat lagi sebesar 9.8 menjadi 78.8 pada siklus II. Peningkatan pencapaian keberhasilan siswa dari pratindakan, siklus I, dan siklus II. Siswa yang mencapai kriteria keberhasilan pada pratindakan sebesar $40 \%$, meningkat menjadi $65 \%$ pada siklus I dan menjadi $85 \%$ pada siklus
II.

\section{Pembahasan}

Berdasarkan

hasil

penelitian mulai dari pratindakan sesuai hasil UTS Semester I, siklus I, dan siklus II dapat dijelaskan bahwa penguasaan konsep IPA siswa meningkat setelah penerapan pendekatan kontekstual. Peningkatan produk terlihat dari skor rerata yang diperoleh sebesar 60.6 pada pratindakan sesuai hasil UTS Semester I, meningkat menjadi 69 pada siklus I, dan meningkat lagi menjadi 78.8 pada siklus II.

Pada pratindakan sesuai hasi UTS Semester I, siswa yang telah mencapai kriteria keberhasilan hanya 8 siswa (40\%) dari jumlah keseluruhan 20 siswa. Partisipasi siswa belum terlihat dalam pembelajaran IPA. Siswa masih malu bertanya kepada guru, mengobrol dengan temannya ketika guru sedang menjelaskan, enggan disuruh maju ke depan kelas, dan malu berbicara di depan kelas. Melihat hal ini guru dan peneliti sepakat untuk meningkatkan penguasaan konsep IPA siswa dan memperbaiki praktek pembelajaran dengan penerapan pendekatan kontekstual.

Pada siklus I, siswa yang mencapai kriteria keberhasilan meningkat menjadi 13 siswa $(65 \%)$ dari 20 siswa. Pembelajaran IPA 
pada siklus I sudah menerapkan pendekatan kontekstual. Langkahlangkah pembelajaran dengan menggunakan pendekatan kontekstual yaitu: 1) siswa dilatih untuk belajar bekerja, menemukan, mengkonstruksi sendiri pengetahuan dan keterampilan barunya, siswa diarahkan untuk melaksanakan kegiatan inquiry, kembangkan rasa ingin tahu siswa dengan bertanya, 4) ciptakan masyarakat belajar, agar siswa dapat bekerja sama dengan siswa lain dan saling bertukar pengetahuan, 5) hadirkan model, 6) lakukan refleksi di akhir pertemuan, dan 7) lakukan penilaian nyata, dengan cara ini penguasaan konsep IPA siswa dapat diukur (Trianto, 2010:111).

Proses pembelajaran IPA dengan menerapkan langkah- langkah pendekatan kontekstual yang tepat berangsur-angsur akan meningkatkan penguasaan konsep IPA siswa. Keterlaksanaan pendekatan kontekstual pada siklus I terlihat dalam pembelajaran IPA selama tindakan siklus I. Siswa tidak lagi mengobrol saat guru sedang menjelaskan, beberapa siswa sudah mau bertanya, siswa mau maju dan berbicara di depan kelas walaupun harus ditunjuk oleh guru. Dibalik keterlaksanaan tersebut, tindakan siklus I juga masih mempunyai beberapa hambatan.

Pada siklus II hasil penelitian menunjukkan bahwa sebanyak 17 siswa (85\%) sudah mencapai kriteria keberhasilan yang ditentukan.
Guru melaksanakan pembelajaran berdasarkan perbaikan yang telah direncanakan sebelumnya. Guru menciptakan pembelajaran yang menyenangkan dengan memutarkan video. Siswa menjadi antusias dalam pembelajaran. Siswa tidak malu bertanya setelah pemutaran video berakhir jika ada yang belum dipahami.Siswa merasa senang karena pembelajaran menggunakan media nyata yang dibawa dari rumah. Siswa dapat mengamati secara jelas hewan dan tumbuhan yang mereka bawa. Setiap anggota kelompok mengemukakan pendapatnya dalam diskusi. Partisipasi siswa meningkat, siswa yang pasif sudah ikut aktif bekerja sama dalam kelompok. Siswa sudah tidak malu-malu lagi maju mempresentasikan hasil diskusi di depan kelas dengan suara yang lantang. Hal ini menunjukkan penguasaan konsep IPA siswa yang tinggi, karena siswa mulai menguasai konsep-konsep dalam IPA yaitu konsep tentang tempat tumbuhan menyimpan cadangan makanan, bagian-bagian tumbuhan yang dimanfaatkan oleh manusia dan hewan untuk makanannya.

Siswa sudah tidak malu-malu lagi maju mempresentasikan hasil diskusi di depan kelas dengan suara yang lantang. Hal ini menunjukkan penguasaan konsep IPA siswa yang tinggi, karena siswa mulai menguasai konsep- konsep dalam IPA yaitu konsep tentang tempat tumbuhan 
menyimpan cadangan makanan, bagian-bagian tumbuhan yang dimanfaatkan oleh manusia dan hewan untuk makanannya, adaptasi hewan terhadap lingkungan, serta adaptasi tumbuhan terhadap lingkungan. Selain konsep yang telah dikuasai siswa ada pula konsep yang belum dikuasai siswa.

Dari observasi dan refleksi yang dilakukan guru dan peneliti, pelaksanaan pembelajara IPA dengan penerapan pendekatan kontekstual telah sesuai dengan yang diharapkan. Sebagian besar siswa sudah berpartisipasi dalam pembelajaran. Hasil penelitian juga menunjukkan bahwa siswa dapat melaksanakan pembelajaran dengan menggunakan pendekatan kontekstual dengan baik sehingga penguasaan konsep IPA siswa meningkat.

Dari uraian di atas dapat disimpulkan bahwa penerapan pendekatan kontekstual untuk meningkatkan penguasaan konsep IPA siswa kelas VA SD N 064960 Medan dinilai berhasil.

\section{SIMPULAN}

Berdasarkan hasil penelitian dan pembahasan pada bab sebelumnya, penerapan pendekatan kontekstual dapat meningkatkan penguasaan konsep IPA siswa. Peningkatan terlihat setelah penerapan pendekatan kontekstual pada siklus I dan siklus II sebagai berikut.
1. Skor rerata pada hasil nilai UTS semester I, menunjukkan bahwa penguasaan konsep IPA siswa rendah. Terbukti bahwa nilai rata-rata kelas baru mencapai 60.6, sedangkan persentase ketuntasannya adalah $40 \%$. Pada siklus I, dilakukan pembelajaran IPA dengan penerapan pendekatan kontekstual nilai ratarata kelas meningkat menjadi 69 , sementara persentase ketuntasan meningkat menjadi $65 \%$.

2. Skor rerata pada hasil nilai UTS semester I, menunjukkan bahwa penguasaan konsep IPA siswa rendah. Terbukti bahwa nilai rata-rata kelas baru mencapai 60.6, sedangkan persentase ketuntasannya adalah $40 \%$.

3. Pada siklus I, dilakukan pembelajaran IPA dengan penerapan pendekatan

kontekstual nilai rata-rata kelas meningkat menjadi 69, sementara persentase ketuntasan meningkat menjadi $65 \%$.

4. Pada siklus II, dengan adanya perbaikan pembelajaran IPA dengan penerapan pendekatan kontekstual yang disertai pemberian motivasi, dorongan, arahan, dan pembagian kelompok secara heterogen yang sesuai dengan kelompok diskusi dari guru menjadikan siswa berani untuk bertanya, mengukapkan pendapat dalam diskusi dan kerja 
kelompok, tidak malu ketika maju mempresentasikan hasil diskusi kelompok, serta mampu berbicara di depan kelas dengan suara yang lantang, semaki meningkatkan penguasaan konsep IPA siswa. Nilai rata-rata kelas meningkat menjadi 78.8, sedangkan persentase ketuntasannya meningkat menjadi $85 \%$.

Berdasarkan kesimpulan di atas, peneliti memiliki beberapa saran sebagai berikut.

1. Bagi Siswa

a. Siswa dapat menerapkan penguasaan konsep IPA yang telah dimiliki dalam kehidupan sehari-hari

b. Siswa hendaknya lebih berani bertanya, jika ada konsepkonsep IPA yang belum dikuasai.

2. Bagi Guru

a. Guru hendaknya memilih metode dan pendekatan pembelajaran yang dapat melibatkan partisipasi siswa secara aktif dalam pembelajaran IPA.

b. Guru dapat menerapkan pendekatan kontekstual pada mata pembelajaran lain yang sesuai.

3. Bagi Peneliti Lain

a. Hasil penelitian dapat digunakan sebagai acuan kepada peneliti lain hasil penelitian. b. Dapat digunakan untuk menambah ilmu pengetahuan terhadap penelitian yang akan dilakukan.

\section{DAFTAR PUSTAKA}

Desmita. 2011. Psikologi Perkembangan Peserta

Didik. Bandung: PT. Remaja Rosdakarya.

Dheni Fedianto. 2011. Meningkatkan Keterampilan Operasi Hitung Melalui Pendekatan CTL (Contextual Teaching and Learning) Kelas IV SD Negeri 2 Pagerandong Pubalingga. Skripsi. Pendidikan Guru Sekolah Dasar UNY.

Elin Rosalin. (2008). Gagasan Merancang Pembelajaran Kontekstual. Bandung: PT. Karsa Mandiri Persada.

E. Mulyasa. (2009). Implementasi Kurikulum Tingkat Satuan Pendidikan. Jakarta: PT. Bumi Aksara.

Lorin W.Anderson dan David R.Krathwohl (2010). Kerangka Landasan Untuk Pembelajaran, Pengajaran, dan Asesmen. Yogyakarta: Pustaka Pelajar.

Martinis Yamin. (2013). Strategi \& Metode dalam Model Pembelajaran. Jakarta: Referensi (GP Press Group) Masnur Muslich. (2011). 
KTSP Pembelajaran Berbasis

Kompetensi dan

Kontekstual. Jakarta:

PT. Bumi Aksara.

Muslichach Asy'ari. (2006). Penerapan Pendekatan Sains- TeknologiMasyarakat Dalam

Pembelajaran Sains di Sekolah Dasar. Yogyakarta: Universitas Sanata Dharma. 